\title{
'N ONTLEDING VAN DIE INVLOED EN VERMOË VAN \\ KORTAFSTANDLUGVERVOERSTEUN OP EENHEIDSTAKTIESE BEPLANNING EN OPERASIES EN AANBEVELINGS HOE HIERDIE STEUN TOT DIE MAKSIMUM BENUT KAN WORD.
}

Lt F. J. VIVIER, SALM **

It was only as a result of the enormous technological progress in the field of arms and the development of modern tendencies in the strategy and tactics of warfare, that the influence of an efficiently co-ordinated ground - and air force on the course of a conventional war was analysed. The purpose of this article is to analyse the influence of short-distance air transport support on unit tactical planning and operations and to make recommendations for the manner in which this support may be utilized to the full.

\section{INLEIDING}

Reeds sedert die Eerste Wêreldoorlog en daarna, veral gedurende die Tweede Wêreldoorlog, het militêre strateë hulself van die geweldige moontlikhede van 'n lugmag in oorlogvoering vergewis. Desnieteenstaande het die lugmag aanvanklik 'n redelik eensydige, onafhanklike en ondergeskikte rol in oorloë gespeel. Dit was eers met die geweldige tegnologiese vooruitgang op die gebied van wapentuig en die ontstaan van moderne tendense in die taktiek en strategie van oorlogvoering dat die invloed van 'n doeltreffend gekoördineerde grond- en lugmag op die verloop van 'n konvensionele oorlog besef is.

Dit is die doel van hierdie ontleding om eerstens die invloed wat kortafstandlugvervoersteun op eenheidstaktiese beplanning en operasies kan uitoefen, te bepaal en om dan die vermoë daarvan in die breë aspek te ondersoek. Ten slotte sal gepoog word om aanbevelings te maak oor hoe hierdie steun maksimaal benut kan word.

\section{OM DIE INVLOED WAT KORTAFSTAND. LUGVERVOERSTEUN OP EENHEIDS. TAKTIESE BEPLANNING EN OPERA- SIES KAN UITOEFEN TE BEPAAL}

Om sodanige invloed te bepaal moet die begrip kortafstandlugvervoersteun eers omskryf word. Onder lugvervoersteun gedurende operasies word bedoel taktiese- sowel as slagveld lugvervoersteun. Dit word in twee tipes operasies onderverdeel, naamlik:

a. lugvervoerde operasies

b. luglogistiekesteun-operasies.

Aangesien hierdie bespreking van lugvervoersteun slegs beperk is tot dié oor kort afstande, moet dit gedefinieer word as lugvervoersteun binne 'n spesifieke operasionele gebied. Wat betref die tipe vliegtuie wat geskik is, kan alle vliegtuie in die volgende kategorieë doeltreffend vir hierdie doel aangewend word:
a. mediumafstandlugvervoer vliegtuie
b. vastevlerk kortafstandlugvervoer vliegtuie
c. ligte vastevlerk vliegtuie
d. helikopters.

Die invloed van kortafstandlugvervoersteun op eenheidstaktiese beplanning en operasies kan derhalwe gesien word in die lig van die potensiaal wat sodanige steun in die aanwending daarvan deur die grondmagte in operasionele optrede het. Hierdie wyses is reeds gedefinieer as die vermoë tot lugvervoerde operasies en luglogistiekesteun-operasies. Lugvervoerde operasies kan onderverdeel word in: 

a. lugstorm-operasies
b. luglandingsoperasies
c. lugvervoerde klandestine-operasies.

Luglogistiekesteun-operasies is die onderhoud van magte in die operasionele gebied per lug. Dit sluit in taktiese- sowel as slagveldlugloqistiekesteun-operasies.

As sulks bied die aanwending van kortafstandlugvervoersteun op eenheidstaktiese beplanning en operasies onder andere die volgende voordele:

a. taktiese mobiliteit

b. sneller konsentrasie van magte

c. verhoogde slaankrag van grondmagte agv sneller aanwending

d. ekonomiese aanwending van grondmagte, aangesien die getalsgewys kleiner mag met sy groter mobiliteit dieselfde slaankrag as 'n groter mag met beperkte mobiliteit gedurende operasies besit.

e. groter trefafstand van grondmagte agv groter mobiliteit

f. beter onderhoud van magte dmv lugvervoerde voorsiening van personeel en toerusting, afvoer van verliese, ens

g. meer effektiewe aanwending van troepe in onbegaanbare terrein.

Hierdie voordele dui op die invloed wat sodanige aanwending van lugvervoersteun het. Die lys is egter nie voldoende nie; derhalwe word die invloed dus duideliker omskryf wanneer die vermoë van kortafstandlugvervoersteun ondersoek word.

\section{DIE VERMOË VAN KORTAFSTANDLUG- VERVOERSTEUN}

Die vermoë van kortafstandlugvervoersteun op eenheidstaktiese beplanning en operasies kan gesien word as die wyse waarop die steun aangewend word om bogenoemde invloed teweeg te bring. In hierdie opsig moet besef word dat oorwinning dmv lugkrag slegs 'n illusie is en dat sukses slegs behaal kan word wanneer die lugmag in 'n strategiese en taktiese ondersteuningsrol as deel van 'n gekoördineerde lug- grond operasie ${ }^{1}$ aangewend word. Die lugmag se optrede is dus in ' $n$ meerdere mate ' $n$ middel ter bereiking van die globale doel en nie die doel op sigself nie.

Lugvervoerde operasies is nie 'n nuwe konsep nie. Dit is 'n ou konsep wat nuwe betekenis gekry het in die geweldig veeleisende oorlogvoering van die huidige tydsbegrip. Dit is veeleisend in dié opsig dat die moontlike aanwending van mannekrag, tegnologie, taktiek en strategie totaal is.

'n Ontleding van die elemente van lugvervoerde oorlogvoering dui daarop dat betreffende die lugvervoerde vermoë van grondmagte lugmobiliteit 'n spesiale graad van mobiliteit en buigsaamheid aan die grondmagte gee: vertikale omvleueling benut die voordeel van die nuwe mobiliteit om bó-oor vyandelike gebied te vlieg en die vyandelike flank vanaf die onbewaakte dws vertikale flank, te omvleuel. Hierdie eienskappe van lugmobiliteit en vertikale omvleueling is die enigste noodsaaklike elemente van lugvervoerde oorlogvoering. ${ }^{2}$

Die lugvervoerde vermoë is dus nie 'n wapen nie, maar 'n metode. Maurice Tugwell het dit só gestel dat ' $n$ infanteriegroep in 'n helikopter nie 'n nuwe wapen is nie: dit is 'n ou wapen wat op 'n nuwe wyse vervoer word, sodat die waarde van hierdie nuwe mobiliteit lê in wat dit hierdie infanteriegroep, wat op hierdie wyse vervoer word, in staat stel om te doen wanneer hulle weer op die grond arriveer. $^{3}$

Ten spyte van sommige militêre kritici se bevraagtekening van die toekoms van lugvervoerde oorlogvoering in die gewapende magte van 'n land, is daar 'n definitiewe toekoms vir hierdie nuwe metode van oorlogvoering. Sedert sy ontstaan het die lugvervoerde konsep deur die oorloë in Korea, Algerië, Viëtnam ${ }^{4}$ en die Midde-Ooste ruim ontwikkel tot 'n uiters doeltreffende metode. So het hierdie konsep in Viëtnam, waar die Amerikaanse magte dit ten volle benut het, duidelik sy waarde getoon. Daarom vind ons ook op logistieke vlak dat die bevoorrading van troepe per lug ten tye van 'n taktiese krisis die aanvaarde wyse van logistieke steun geword het. Hedendaagse oorloë is geweldig mobiel aangesien die mag wat die vinnigste en gouste kan beweeg en aanval, duidelik die voordeel bó die verdediger het. In hierdie opsig is beweging per lug die snelste vervoermetode bekend; dus lê die sleutel tot suksesvolle oorlogvoering in die toekoms juis dáárin. ${ }^{5}$ 


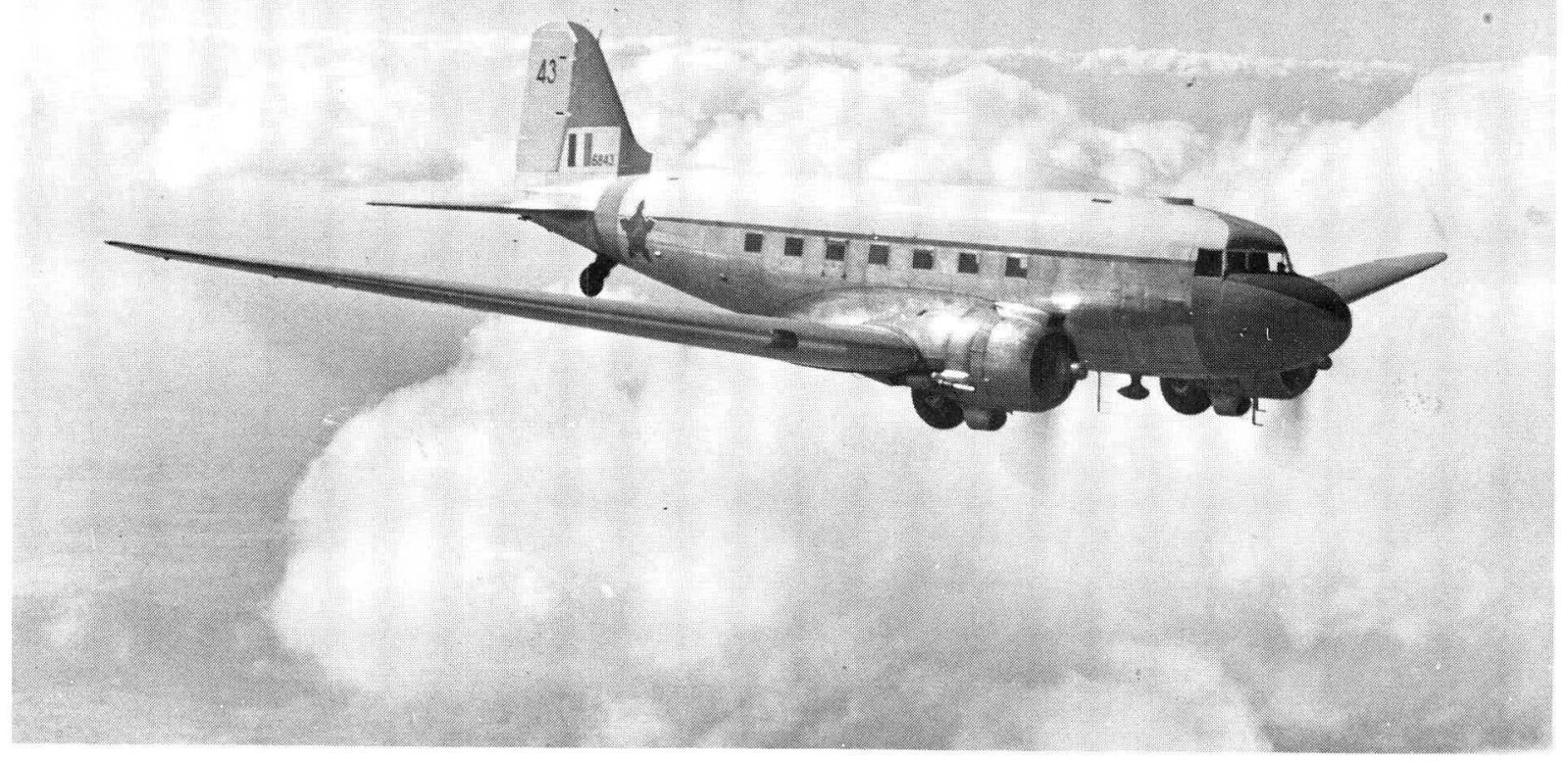

Dakota

Allouette

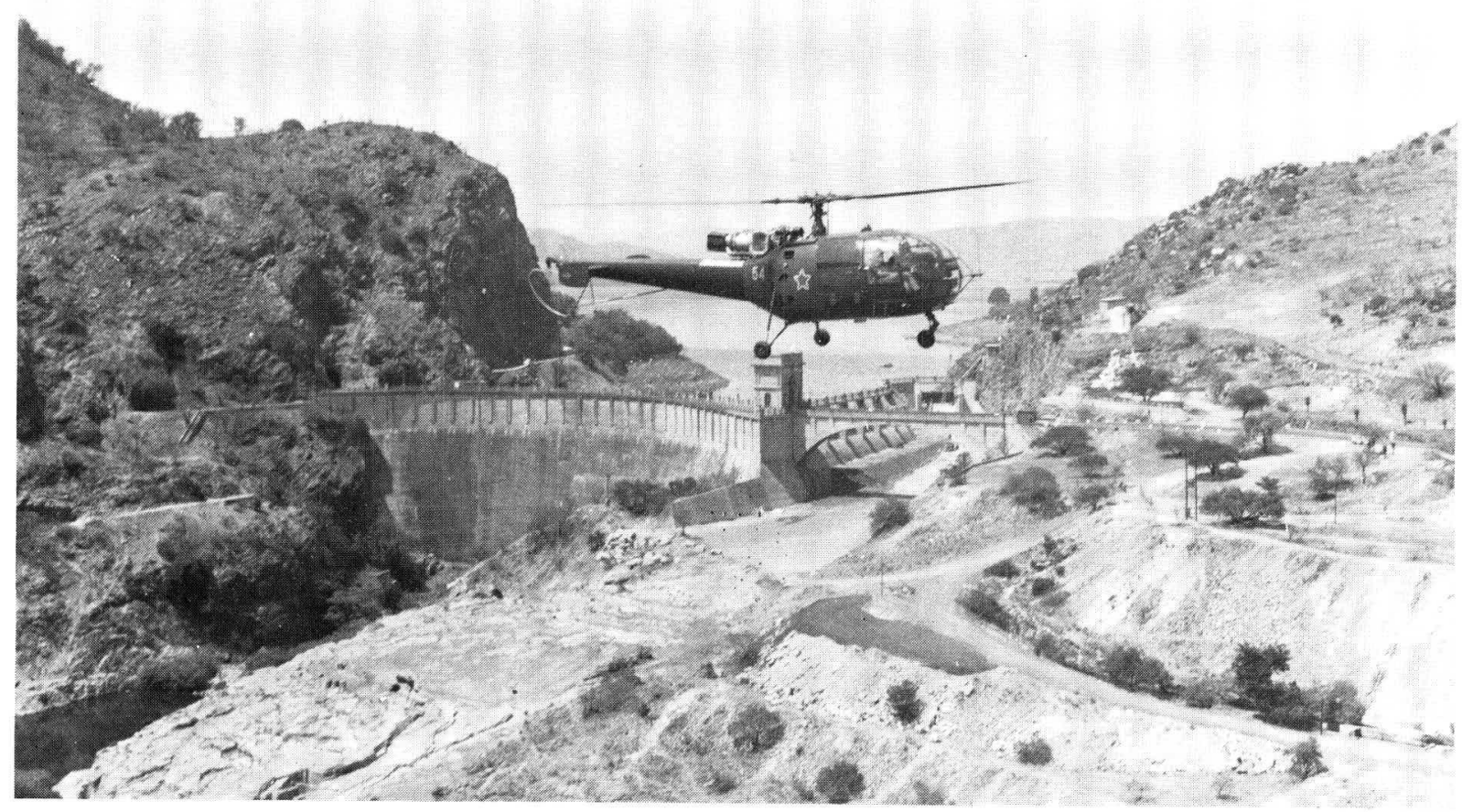




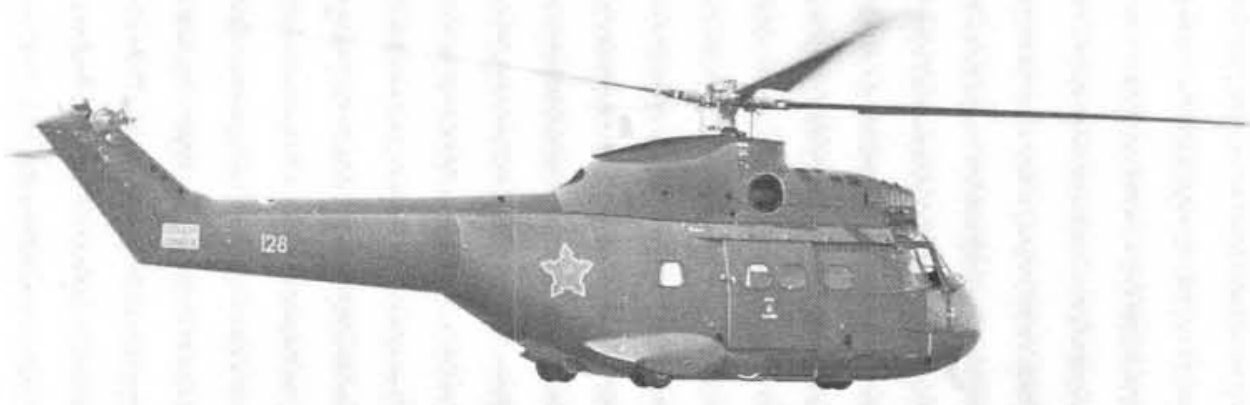

Puma

'n Jeep-gemonteerde XX7184-2 hoë-frekwensie enkel syband sendontvanger in die proses om aan boord van 'n VSA Marinierskorps C-130 Hercules gelaai te word.

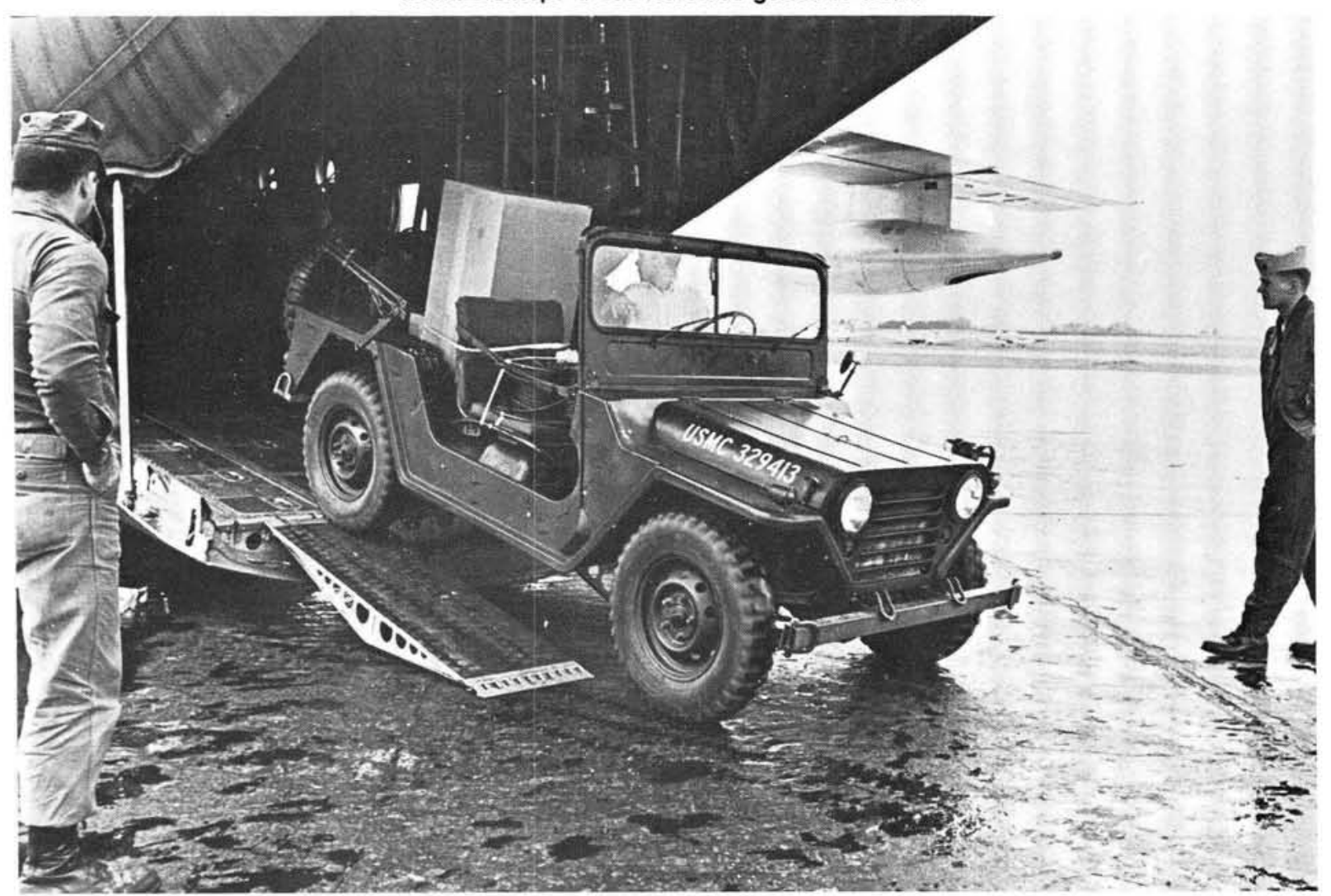


Vervolgens wil aan die hand van verskeie tipes lugvervoerde operasies die algemene voordele, eienskappe en derhalwe die vermoë van die metode van lugvervoerde oorlogvoering omskryf word:

\section{Mobiliteit}

Die eienskap van gevorderde mobiliteit is seker een van die mees belangrike voordele van die lugvervoerde metode. In 'n beperkte oorlog is hierdie lugmobiliteit noodsaaklik vir die meer gesofistikeerde verdediger om vyandelike bewegings in moeilike terrein te beperk en lam te lê. Lugvervoerde operasies vervang op sigself nie die tradisionele grondmag se funksie om-die gebied te behou en met gekonsentreerde vuurkrag en massa-aanwending die vyand te oorkom nie. In dié verband gee helikopters byvoorbeeld dmv lugvervoerde optredes bystand vir 'n hoofoperasie met snelle reaksiespoed, buigsaamheid en noue samewerking met grondmagte, sodat die hoofaanval verander word in 'n driedimensionele aanslag. Netso gee die vastevlerk troepedraers in die moderne oorlogsteater die verdediger die vermoë om vinniger weerstand en reserwes as die vyand op te bou. ${ }^{6}$ Die waarde van lugmobiliteit is dus velerlei: die vermoë om vinnig binne ' $n$ bedreigde gebied te ontplooi, ${ }^{7}$ om die aanmars van ' $n$ vyandelike mag te steun en om troepe binne 'n operasionele gebied sneller te vervoer. $^{8}$

'n Belangrike voordeel wat die lugvervoerde vermoë aan ' $n$ aanvaller of verdediger bied, is dié eienskap dat die aanvalsmomentum ongehinderd kan voortgaan in gevalle waar spesifieke probleemsituasies die gewone grondmag feitlik tot stilstand sou dwing, vanweë die onvermoë om vertikaal op te tree, dws te onttrek of te ondersteun. In hierdie opsig is die lugvervoerde mag. vergeleke met die grondmag, nie so afhanklik van terreinaspekte in die verkryging en behoud van momentum nie. Vanweë hierdie gevorderde vlak van mobiliteit het die lugvervoerde mag dié voordeel dat dit nie gebonde hoef te wees aan ' $n$ spesifieke terreindoelwit nie, maar dat 'n doelwitoriëntasie tov ' $n$ spesifieke vyandelike mag gehandhaaf kan word.

\section{Verrassing}

Die uitsonderlike verrasingselement wat verkry word deur die georuik van lugvervoerde troepe is alombekend. ' $\mathrm{n}$ Sprekenae historiese voorbeeld is die geweldige suksesse wat die Duitse valskermtroepe gedurende die openingsfase van die Duitse offensief met hul aanvalle op die Belgiese verdedigingslinies by die Albert Kanaal net wes van die Belgiese grens agv die verrassingselement behaal het. ${ }^{10}$ Die sielkundige effek van 'n lugvervoerde aanval vergeleke met enige ander wyse van aanval moet nie onderskat word nie. Alhoewel die Duitse lugvervoerde magte groot verliese gely het in die Laaglande in 1940, het dié aanvalle 'n geweldige moraalafbrekende effek gehad op die vyandelike ver,dediging en bygedra tot die uiteindelike oorwinning. Dieselfde resultate is deur die VSA in Viëtnam vermag. Betreffende konvensionele oorlogvoering het die Tweede Wêreldoorlog hier gewys dat lugvervoerde oorlogvoerıng 'n potensieel baie doeltreffende uitbuiting van 'n gunstige lugsituasie is. Hier is lugvervoerde troepemagte in samewerking met grondmagte op dieselfde wyse aangewend as in die tvd van die kavallerie speerpunt: vir die 'coups de main', om die vyand dmv verrassıng en skok te verwar, en om die beweging van die swaarder grondmagte dmv " lugvervoerde tapyt te versnel. ${ }^{11}$

Dit is vermag deurdat elke militêre operasie uit die aard van die saak basies ' $n$ beweging in tyd en ruimte is en die spoed waarmee ' $n$ beweging uitgevoer kan word 'n voorwaarde is vir sy sukses. Dit is hierdie spoed in beweging wat daardie noodsaaklike element in oorlogvoering, naamlik verrassing, voorsien en wat deur die klassieke aanwending van die lugvervoerde metode ook regdeur die Tweede Wêreldoorlog verkry is. ${ }^{12}$

\section{Buigsaamheid}

Die lugvervoerde vermoë gee verder 'n nuwe buigsaamheid in aanval deur die grondmagte. ${ }^{13}$ Dit word voorsien deur die lugmobiliteit wat die reaksietyd in operasies drasties verkort, die grondmagte 'n sneller ontplooiingsvermoë gee en die verdediging se hoër mobiliteit dus in aanval omskep. Hierdie buigsaamheid is geleë in die vermoë tot aanpasbaarheid met die teenkoms van taktiese probleemsituasies in die onmiddellike gevegsarea, vanweë die vermoë tot driedimensionele optrede in aanval en verdediging, vergeleke met die beperkende tweedimensionaliteit van die gewone grondmag se optrede.

\section{Meerdoeligheid in Aanwending}

Lugvervoerdde magte het vervolgens die voordeel van meerdoeligheid in aanwending. Dit bestaan onder andere uit die vermoë tot snelle opbou van magte wat taktiese verrassing teweeg- 
bring agv die gekonsentreerde ontplooiing van magte. Verder het die lugvervoerde troepemagte die vermoë om as 'n lugmobiele mag of as infanterie op die grond aangewend te word, sodat dit 'n addisionele dimensie aan die lugvervoerde vermoë verleen. Ook besit die lugvervoerde troepe die eienskap dat hulle as 'n tradisionele elite vegselement 'n gespesialiseerde opleiding geniet wat nie aan gewone infanterie gevegsmagte gebied word nie. ${ }^{14}$ Laastens geniet die lugvervoerde eenheid dié voordeel dat dit behalwe vir die hoofdoel ook terselfdertyd aangewend kan word in verskeie ander rolle. Volgens die Amerikaanse voorbeelde in Viëtnam kan die lugvervoerde eenheid oa gebruik word vir grondmagondersteuning deur die helikopter met 'n verskeidenheid van wapens toe te rus, vir verkenning van terrein en vyandelike bewegings, vir afvoer van verliese, vir vliegtuigherwinning, propaganda, sowel as in die rol van ' $n$ Voorste Lugbeheerder ten tye van 'n gesamentlike lug-grondoperasie.

\section{Oorlewing}

'n Belangrike maatstaf by die ontleding van die vermoë van 'n gevegsmag se potensiaal is of sodanige mag kan oorleef op die grond, afhangend van die grootte van die mag, sy taak en die vermoë en moontlike reaksie van die vyand. Indien in ag geneem word dat dit die lugvervoerde element se taak is om die vyand aan te val, te vernietig en sy kommunikasielyne af te sny, en nie om noodwendig brughoofde te behou totdat hulle deur die grondmagte verlig word nie, kan die lugvervoerde mag hierdie taak suksesvol uitvoer aangesien sy opleiding daarvoor voorsorg tref. Die oorlewingsvermoë van hierdie mag word ook behou deur die maksimum aanwending van verowerde vyandelike uitrusting en voorrade. Verder het die lugvervoerde mag ook die voordeel dat hy verrassing en kragdadige, onverskrokke optrede tot die maksimum uitbuit en gebruik ter verwesenliking van sy doel. $^{15}$ Hierdie eienskap verseker maksimum waarskynlikheid vir oorlewing, aangesien bogenoemde faktore die vereistes vir suksesvolle optrede deur die lugvervoerde mag is.

\section{Eienskappe van Lugvervoerde Magte soos deur die USSR aangewend}

Vuurkrag, maneuvreringsvermoë en snelle aanmars gedurende operasies is belangrike beginsels van die Sowjet-Unie se offensiewe doktrine. Hierin word vandag in al hoe groter mate staatgemaak op die Russiese lugvervoerde magte. Gedurende verskeie Russiese militêre oefeninge, waaronder die Dniepr (1967), die Dvina (1970) en die Yug (1971) ${ }^{16}$ het verskeie kenmerke van die Russe se gebruik van lugvervoerde troepemagte na vore gekom.

In die Dnieper-oefening is byvoorbeeld suksesvol geillustreer hoe doeltreffend lugvervoerde magte in lugstorm-operasies aangewend kan word. In die Dvina-oefening is die vermoë van lugvervoerde troepe om teen vyandelike tenkaanvalle te verdedig, uitgewys. In die Yug-oefening is ' $n$ suksesvol gekombineerde lugstorm- en luglandings-operasie uitgevoer. Dit blyk dus dat die Sowjet-Unie 'n potensiële lugvervoerde bedreiging besit waar die taktiese toepassing en aanwending van lugvervoerde magte in oorloë op alle vlakke van intensiteit geskied. ${ }^{18}$ Samevattend word die Sowjet-Unie se lugvervoerde eenhede dus gebruik om die volgende take te verrig:

\section{a. rivieroorgange in te neem}

b. gedeeltes van kusgebiede in te neem

c. gebruik van reserwes deur vyand te verhoed

d. sleutelgebiede in bergagtige areas te beset

e. terugtrekking deur vyand te verbrokkel

f. snelle verkenning ná kern of chemiese aanslag

g. vernietiging van bevel- en beheerfasiliteite

h. vernietiging van kernwapenstelsels

j. beslaglegging op watervoorsiening in woestyngebiede

k. inbesitneming van padverbindings in poolgebiede. ${ }^{19}$

Dit wil dus voorkom asof die Russiese strateë die potensiële vermoëns van die lugvervoerde taakmag duidelik besef het en aangewend het in hul beplanning. Op taktiese sowel as strategiese vlak het die USSR ook die voordele van die aanwending van 'n lugvervoerde tapyt, op die grondslag van Operasie Market Garden gedurende die Geallieerde Teenoffensief in April 1944, deeglik besef. Sodanige lugtapyt, veral wanneer aangewend op ' $n$ kleiner skaal, berei die weg voor vir die snelle opmars van die oprukkende grondmagte in die onmiddellike gevegsgebied, en versnel sodoende hul voor- 
waartse momentum. In die opsig van kortafstandlugvervoersteun word hierdie taakmagte byvoorbeeld aangewend mbv helikopters om spronggewys voor die sneloprukkende grondmagte vyandelike verdediging omver te gooi, ${ }^{20}$ met sodanige doelwitte só gekies om die onversteurde aanmars van die hoofmag te verseker.

Hier is die relatief snelle aaneenskakeling tussen die lugvervoerde eenhede en die hoofelement van primêre belang. ${ }^{21}$

\section{Invloed van Helikopters}

Vervolgens is dit noodsaaklik om die belangrike nuwe invloed van die helikopter in lugvervoerde operasies uit te lig. Ten tyde van Viëtnam was dit duidelik dat die helikopter met kortafstandlugvervoersteun as 'n metode van aflewering relatief meerderwaardig teenoor die valskerm was. Nogtans word die valskerm steeds gebruik omdat die helikopter in spesifieke operasionele take nie (snelheid- en afstandsgewys) met vastevlerkvliegtuie kan kompeteer nie..$^{22}$ Reeds sedert 1960 het die Sowjet-Unie 'n soortgelyke beskouing gehuldig. ${ }^{23}$ In dié verband is ook die Geallieerde Europese Bevel Mobiele $\mathrm{Mag}^{24}$ sowel as verskeie ander Europese weermagte voldoende toegerus met helikopters. So het die Egiptiese magte gedurende die Yom Kippuroorlog suksesvolle diep-indringende helikoptervervoer stormaanvalle teen Israeli verdediging geloods. ${ }^{25}$ Soortgelyke operasies is met groot sukses deur die Siriese Magte teen Israeli uitkykposte gevoer. ${ }^{26}$

In verskeie opsigte het die helikopter sy vermoë om 'n aanval vanaf die onmiddellike gevegsarea te loods, akkurate aflewering, relatiewe ignorering van weersomstandighede, en die kontinuitteit van troepmobiliteit ná landing dmv herontplooiing of onttrekking duidelik bewys. ${ }^{27}$ Wat betref aanwending in kortafstandlugvervoersteun operasies blyk die helikopter dus ideaal te wees.

\section{Lugvervoerder Pantser}

Ten slotte word na die potensiaal van lugvervoerde pantser in die stigting en verdediging van 'n brughoof agter vyandelike linies verwys, waardeur oa die taktiese en strategiese mobiliteit en slaankrag vergroot word. ${ }^{28}$ Reeds geruime tyd word veral die helikopter aangewend as ' $n$ stabiele platvorm vir die aanwending van masjiengewere, kanonne en missiele teen vyandelike bedreiging in die vorm van verdedigingstellings, troepe-ontplooiing, pantserspeerpunte, sowel as 'n lugwaartse vyandelike bedreiging. Daar is reeds ver gevorder met die samevc is van sodanige aanvalshelikopters by heli wiververvoerde magte, om die slaankrag en ooriawingsvermoë van die geïntegreerde lugvervoerde mag geweldig te verhoog.

Soos alreeds vermeld is luglogistieke ondersteuning die onderhoud van ' $n$ grondmag per lug. Dit sluit in lugvoorsiening, die vervoer van personeel en toerusting, die afvoer van verliese en krygsgevangenes, asook die onttrekking van toerusting. Uit die aard van die saak word lugvervoer slegs aangewend wanneer daar regverdiging daarvoor is, aangesien dit aansienlik duurder as die normale pad- of spoorvervoer is. Dit is ' $n$ aanvaarde beginsel dat effektiewe logistieke steun die sleutel bied tot volgehoue oorlogvoering. Dit word deeglik deur logistieke beplanners besef sodat lande soos die SowjetUnie hierdie steun tot die maksimum probeer uitbou het deur die voordele van die lugvervoerde vermoë doeltreffend in hul logistieke stelsel aan te wend. ${ }^{29}$ In hierdie opsig bied die vermoë van lugvervoer op logistieke vlak onder andere aan grondmagte 'n groter reikafstand, langer tydsduur van operasies, en verhoogde aanpassingsvermoë van die logistieke stelsel onder operasionele omstandighede agv van die driedimensionaliteit wat lugvervoer aan 'n logistieke stelsel verleen.

Daar heers ' $n$ noue balans tussen ' $n$ operasie en sy logistieke steun. Hulle is nou verbind en uiters afhanklik van mekaar, en die afwesigheid van die een of die ander voorspel rampspoedigheid op die slagveld. ${ }^{30}$ In die lig hiervan dui die driedimensionaliteit van luglogistieke steun op die beter operasionele potensiaal van ' $n$ grondmag. Juis daarin lê die besondere vermoë van luglogistieke steun.

\section{AANBEVElings VIR die MAKSimale BENUTTING VAN KORTAFSTANDLUG. VERVOERSTEUN}

Dit is moeilik om in hipotetiese terme die voordele van 'n metode waar soveel afhang van tydsberekening, durf en subtiele optrede, te illustreer, omdat hierdie metode ' $n$ ineenvloeiing van so baie faktore, waarvan die graad van waarskynlikheid moeilik bepaalbaar is, verteenwoordig. ${ }^{31}$ Die aard van hierdie faktore wissel vanaf die voorbereiding, beplanning en koördinasie van die operasie, tot die doeltreffendheid van die organisasie op stafvlak. Nogtans kan verskeie faktore geëlimineer word deur vir elkeen sover moontlik voorsiening te maak. 'n Bespreking van sommige volg hieronder. 


\section{Opleiding van Personeel}

Betreffende die faktor van die opleiding van troepe kan die lugvervoerde aanvoerder nie altyd soos sy eweknie op die grond vyandelike gebiede patrolleer of die toekomstige reaksies van die vyand onder aanval vooruitbepaal nie. Dus is die tipiese lugvervoerde operasie onderhewig aan verskeie onvoorspelbare faktore. Die taakmag en roete is kwesbaar vir grond-tot-lug missiele, vegvliegtuie en lugafweerkanonne. Die landing kan selfs onder ongure omstandighede plaasvind. Die totale aantal troepe en onmiddellike reserwes en ondersteuningswapens is beperk en moet geïsoleerd aangewend word. Taktiese mobiliteit op die grond is beperk wanneer vervoer nie meer mbv helikopters kan geskied nie. Hierdie probleme kan gedeeltelik voorkom word deur die ervaring en opleiding van die lugbemanning en lugvervoerde troepe. Aangesien troepedraers altyd beperk is, moet elke operasie geslaagd uitgevoer word. Dit kan verseker word deur die genoegsame voorbereiding en opleiding van troepe. ${ }^{32}$

\section{Beplanning}

Die waarskynlikheid vir sukses kan verder vergroot word wanneer die militêre beplanner 'n duidelike doelwit het en die grondmagte en kortafstandlugvervoersteun gedurende die operasie so doeltreffend moontlik aangewend word. Ten tye van die operasie moet alternatiewe planne deeglik in aanmerking geneem word om die suksesvolle uitvoering van die operasie te verseker sonder dat vermorsing van tyd en doellose aanwending van magte plaasvind. ${ }^{33}$

\section{Verrassing en Tydsberekening}

Verrassing en tydsberekening is essensiële vereistes vir 'n suksesvolle operasie. Laasgenoemde beïnvloed die graad van verrassing, sodat die tydstip waarop die kortafstandlugvervoersteun operasie plaasvind ter ondersteuning van 'n hoofoperasie deeglik in berekening gebring moet word met die beplanning en uitvoering van die operasie. ${ }^{34}$

\section{Kommunikasie}

Doeltreffende kommunikasie tussen lug-engrondmagte is van uiterste belang. Aangesien troepe nie sonder lugsteun daadwerklike optrede kan loods nie, is lugondersteuning by die aanwending van 'n lugvervoerde taakmag net so belangrik. Hierdie steun moet konsentrasie van vuurkrag en die lewering van versterkings en voorrade asook herontplooiing of terugtrekking insluit. In hierdie opsig moet reserwes beskikbaar wees omdat dit die lugvervoerde taakmag die behoud van inisiatief voorsien, teen 'n vyand wat meer mobiel is op die grond. Dit vereis doeltreffende kommunikasie op die slagveld, en tussen die lugmagte, grondmagte en basisbeheer. ${ }^{35}$

\section{Onkonvensionele Oorlogvoering}

Vervolgens wil gewys word op die enorme potensiaal van kortafstandlugvervoersteun operasies in onkonvensionele oorlogvoering. Seymour J. Deitchman het dit treffend só opgesom: 'Potensieel kan ons die wyse beskou waardeur hoogs mobiele operasies, soos benodig vir die snelle taktiese beslissings deur magte van gemiddelde grootte, bereik kan word in die moeilike militêre en geografiese terrein waar onkonvensionele oorloë gewoonlik plaasvind. Militêre operasies sal dus dieselfde karaktereienskappe van maritieme maneuvers besit, waar plaaslike aanwending van militêre mag teen vyandelike sterkpunte, swakpunte of strategiese posisies geskied. Die relatief klein maneuvreringsgroepe sal nie in voortdurende kontak met die vyand verkeer nie, sal moeiliker opspoorbaar wees, en hul aanslae sal die voordele van verrassing behaal, terwyl uitbuiting van die vyand se swakhede plaasvind. ${ }^{36}$

Die aanbeveling wil dus gemaak word dat die besondere vermoë van kortafstandlugvervoersteun in militêre operasies in teen-insurgensie oorlogvoering ten volle uitgebuit moet word mbv die gebruik van die meerderwaardige lugvervoerde metode. Dit is my mening dat die lugvervoerde vermoë vir die konvensionele verdediger teen 'n rewolusionêre aanslag in die huidige tydsbestek nie slegs die vermoë verleen om die vrye optrede van die vyand drasties te beperk nie, maar ook 'n wyse bied om dié vyand teen te staan in terme van sy eie rewolusionêre leerstellings - dit is die vermoë om totale verrassing, mobiliteit, buigsaamheid en ekonomiese aanwending van magte te behaal. Die tradisionele beskerming wat ruimte, terrein en tyd voorheen aan die vyand in rewolusionêre oorlogvoering gebied het, kan nou doeltreffend afgebreek word deur die suksesvolle aanwending van die lugvervoerde vermoë dmv kortafstandlugvervoersteun in vandag se geweldig mobiele oorlogvoering. Die graad van suksesvolle aanwending van die uitsonderlike potensiaal van hierdie vermoë hang direk af van die mate waartoe dit in die gewapende magte van die moderne weermag toegepas en geïntegreer word. 
Daar is reeds gewys op die geweldig verbeterde lugvervoerde vermoë van die USSR. Dit blyk daarvolgens duidelik te wees dat die huidige lugvervoerde bedreiging van die USSR ' $n$ indringende insig vir die taktiese aanwending van veral helikoptervervoerde magte op alle vlakke van oorlogsintensiteit reflekteer. Dit het verseker dat die USSR daarin geslaag het om die doktrines van lugvervoerde oorlogvoering en die gevorderde tegnologie van moderne oorlogvoering suksesvol te integreer, gebaseer op die geslaagde integrasie van die grondliggende beginsels van die lugvervoerde metode deur Amerikaanse lugvervoerde magte in Viëtnam en die meerderwaardige mobiliteit wat daardeur verkry is, om sodoende die eise van moderne konvensionele en spesifiek onkonvensionele oorlogvoering die hoof te bied.

'n Ontleding van die probleme wat ' $n$ onkonvensionele aanslag aan die moderne verdedigingsmag stel, wys duidelik dat die voordele wat die korrekte toepassing van die lugvervoerde metode in die aanwending van kortafstandlugvervoersteun bied, taktiese en daarvolgens strategiese suksesse, wat voorheen moeilik vermag kon word, verseker. Beide die VSA, Frankryk, Brittanje en die USSR het dit alreeds bewys.

Betreffende sodanige onkonvensionele aanslae, moet die weermag wat voor die moontlikheid van 'n toekomstige grootskaalse insurgensiebedreiging oor ' $n$ wye geografiese gebied staan, derhalwe 'n doktrine formuleer, wat as basis die vorming van 'n nuwe totale onafhanklike lugvervoerde (helimobiele) eenheid beliggaam, waarin met die aanwending van die voordele van die taktiese aflewering, ontplooiing en terugtrekking van troepe per helikopter (beskerm en ondersteun deur aanvalshelikopters) geëksperimenteer word. Hierdie totale helimobiele eenheid moet dus die vroeëre konsep van die instandhouding van aparte helikoptereenhede wat volgens behoefte aan troepemagte afgedeel word, vervang, en in die toekoms ontwikkel word tot die vlak van 'n spesialiseenheid waar die oplossing van spesifieke probleemsituasies behoeftes skep wat die aanwending van so ' $n$ spesialiseenheid regverdig.

\section{SLOT}

Indien die vraag gestel word waarom die militêre elite soms die onvermoë toon om strategieë te formuleer wat mbv uitgesoekte en paslike gebruikmaking van nuwe ontwikkelings en tendense, dit sou moontlik maak om 'n duidelike voordeel bó die vyand te bekom, kan verskeie faktore in gedagte gehou word. In hierdie verband is ' $n$ gebrek aan operasionele ervaring en aanwending van lesse geleer, afwesigheid van goedopgeleide uitvoerende- en ondersteuningspersoneel, buitelandse beleidsbeperkings en ' $n$ retrospektiewe militêre ideologie almal belangrike redes vir 'n gebrek aan innovasie. Maar hierdie faktore is ook nou verbonde aan die tradisionele konserwatisme van die offisierskorps. ${ }^{37}$

Bogenoemde veronderstelling moet dus as basis dien vir die aanbeveling dat die militêre beleidsformuleerders van militêre magte hulself terdeë moet vergewis van die potensiaal van kortafstandlugvervoersteun in die moderne mobiele oorlogvoering. Waar die strategiese aanwending van pantser aan die begin van die Tweede Wêreldoorlog die konsepte van oorlogvoering sedert die Eerste Wêreldoorlog totaal verander het, kan aanvaar word dat die aanwending van lugvervoerde troepemagte in toekomstige oorlogvoering 'n soortgelyke rol sal speel.

\footnotetext{
- Lt F. J. Vivier, B. Mil is tans as navigator verbonde aan 28 Eskader LMB Waterkioof.

* Met bostaande artikel wat hy vir Militaria in Prosa omvorm het, het L.t Vivier die Diensgeskrif kompetisie van 1979 gewen.
}

\section{Voetnote}

1. S. Deitschman: The Implications of Modern Technologica Development for Tactical Air Tactics and Doctrines, (Air University Review, November - December 1977 , p 25).

2. M. Tugwell: Airborne to Battle, p 289.

3. Ibid, p 339 .

4. T. R. Milton: From the Airlift to Vietnam and Beyond (Air Force Magazine, February 1979, pp 38-43) W. F. Thompson: Airmobile Warfare in the Mountains (Military Review, July 1970, p 57),

5. M. Alexander: Airborne - What About the Future (Paratus, August 1978, p 28)

6. M. Tugwell: Op cit, p 338.

7. F. K. Ware: The Airborne Division and a Strategic Concept(Military Review, March 1976, p 27)

8. M. Tugwell: Op cit, $p 335$

9. S. Deitschman: Ibid, $p 24$

10. M. Tugwell: Day of the Paratroops (Military Review, March 1977,p 45)

11. M. Tugwell: Airborne to Battle, p 289

12. S. J. Possony: Strategic Air Power - The Pattern of Dynamic Security, p 39

13. F. O. Miksche: Paratroops, p 15

14. F. K. Ware: Op cit, p 30.

15. Ibid, p 32

16. G. H. Turbiville: Soviet Airborne Troops (Military Review, April 1973, p 60)

17. Ibid, pp 66-68.

18. D. A. Bramlett: Soviet Airmobility: An Overview (Military Review, January 1977, p 14).

19. Ibid, p 20

20. Ibid, p 24

21. Ibid, $p$ 19

22. M. Tugwell: Day of the Paratroops, p 51.

23. G. H. Turbiville: A Soviet View of Heliborne Assault Operations (Military Review, October 1975, p 4). 
24. J. Braisby: The ACE Mobile Force (Nato's Fifteen Nations, December 1977 - 1978, pp 82-88).

25. M. Lambert (ed): Helicopter Forces Europe (Flight, 6th August 1977, pp 412-420).

26. SADF Documentation Service: The Yom Kippur War Doctrine - 2: Missiles and Aircraft, No 2 F iii, p 12; SADF Documentation Service: The Yom Kippur War Doctrine - 2; Missiles and Aircraft, No $2 F$ ii, $\mathrm{p} 5$.

27. C. Wakebridge: The Syrian Side of the Hill (Military Review, February 1976, p 21).

28. M. Tugwell: Airborne to Battle, p 328.

29. A. S. Britt: Airborne Armor (Military Review, September 1978, p $60)$

30. G. H. Turbiville: Soviet Logistics Support for Ground Operations (Military Review, July 1976, p 68).

31. W. T. Kerwin: An Old Soldier Speaks (Military Review, March 1979, p 42).

32. S. Deitschman: Op cit, p 341

33. M. Tugwell: Airborne to Battle, p 290

34. Ibid, p 291

35. Loc cit.

36. LoC cit.

37. Ibid, p 340.

38. C. Harvie: Technological Change and Military Power in Historical Perspective (Adelphi Paper No 144, Spring 1978, p 6).

\section{Bibliografie}

\section{Literatuur}

a. Miksche, F. 0.: Paratroops - The Histon; Organization and Tactical Use of Airborne Formations. London, Tweede Uitgawe, 1963.

b. Possony, S. J.: Strategic Air Power - The Pattern of Dynamic Security. Washington, 1949

c. Tugwell, M.: Airborne to Battle - A History of Airborne Warfare 1918 - 1971. London, 1971.

\section{Periodieke Publikasies}

a. Alexander, M.: Airborne - What About the Future. (Paratus, August 1978)

b. Braisby, J.: The ACE Mobile Force, (Nato's Fifteen Nations, Vol 22, No 6. December 1977 - January 1978).

c. Bramlett, D. A. Soviet Airmobility: An Overview (Military Review, Vol 57, No 1, January 1977)

d. Britt, A. S.: Airborne Armor (Military Review, Vol 58, No 9 , September 1978)

e. Deitschman, S.: The Implications of Modern Technological Developments for Tactical Air Tactics and Doctrines (Air University Review, Vol 29, No 1, November - December 1977).

f. Harvie, C.: Technological Change and Military Power in Historical Perspective (Adelphi Paper No 144. Spring 1978).

g. Kerwin, W. T.: An Old Soldier Speaks (Military Review, Vol 59, No 3, March 1979).

h. Lambert, M. (ed): Helicopter Forces Europe (Flight, 6th August 1977)

1. Michael, S. J.: Vietnam: Failure to Follow the Principles of War (Marine Corps Gazette, August 1977).

k. Milton, J. R.: From the Airlift to Vietnam and Beyond (Air Force Magazine, Vol 62, No 2, February 1979).

I. SADF Documentation Service: The Yom Kippur War Doctrine -2 : Missiles and Aircraft, No 2.f.ii.

m. SADF Documentarion Service: The Yom Kippur War Doctrine -2 : Missiles and Aircraft, No 2.f.iit.

n. Thompson, W. F.: Airmobile Warfare in the Mountains (Military Review, Vol 50, No 7, July 1970).

0. Tugwell, M.: Day of the Paratroops (Military Review, Vol 57. No 3, March 1977)

p. Turbiville, G. H.: A Soviet View of Heliborne Assault Operations (Military Review, Vol 55, No 10, October 1975).

r. Turbiville, G. H.: Soviet Airborne Troops(Military Review, Vol 53, No 4, April 1973).

s. Turbiville, G. H.: Soviet Logistics Support For Ground Operations (Military Review, Vol 56, No 7, July 1976).

t. Wakebridge, C.: The Syrian Side of the Hill (Military Review, Vol 56, No 2, February 1976)

u. Ware, F. K.: The Airborne Division and a Strategic Concept (Military Review, Vol 56, No 3, March 1976). 